\title{
Bacterial colonisation of humidifier attachments on oxygen concentrators prescribed for long term oxygen therapy: a district review
}

\author{
N Pendleton, J S Cheesbrough, M J Walshaw, C R K Hind
}

\begin{abstract}
A microbiological survey was undertaken on the eight patients in the Liverpool District who have a humidifier attachment on their oxygen concentrator. All but one of the humidifiers were contaminated with potentially pathogenic bacteria.
\end{abstract}

Microbiological contamination of humidifiers used with ventilators is a documented cause of nosocomial pneumonia, ${ }^{1}$ and bacterial contamination of home nebulisers also occurs. $^{2}$ The possibility of similar contamination of the humidifier attachment of an oxygen concentrator was suggested by a fatal case of community acquired pseudomonas pneumonia in a patient receiving long term oxygen therapy. This prompted an audit of the 48 patients having long term oxygen therapy in the Liverpool District. The aims of the study were to find out how many patients used a humidifier attachment on their oxygen concentrator and how they cleaned such attachments, and to determine whether the humidifier attachments were contaminated.

\section{Patients and results}

A postal and telephone survey was performed to determine how many of the 48 patients in the Liverpool District with an oxygen concentrator were using a humidifier attachment. Fifteen patients had tried a humidifier at some stage, though only eight were using it at the time of this study (seven women, one man; mean age $58 \cdot 2$, range $51-73$ years). All were ex-smokers with severe chronic airflow limitation, who used their concentrators for over 15 hours a day (mean 19.5, range 15-24 hours). Seven patients used the humidifier contin- uously and one intermittently-the latter only during waking hours (mean $8 \cdot 5$, range $8-12$ hours).

All patients changed the humidifier water daily. Methods of cleaning the humidifier varied, six patients using detergent, one bleach and one boiled tap water. After cleaning it all patients filled the humidifier with cold water from the domestic supply.

All eight patients were visited at home at the same time of day, on average seven (range 5-9) hours after the last water change, as they were using the oxygen concentrator. The entire contents of the humidifiers were collected and samples were taken from the humidifier, patient, and cold tap supply for microbiological processing (table 1). All cultures were incubated in humidified air at $37^{\circ} \mathrm{C}$ for up to five days. Organisms present at 100 or more colony forming units $(\mathrm{cfu}) / \mathrm{ml}$ of water were identified and recorded. Growth of $<100 \mathrm{cfu} / \mathrm{ml}$ was not recorded, as very low level colonisation with the relatively nonvirulent organisms typically found in humidifiers would be an unlikely cause of pneumonia. $^{3}$

At each visit the patients were asked about antibiotic use and hospital admissions before and while they had been using the humidifier attachment.

Bacteria were cultured from the humidifier water in seven of the eight cases (table 2), with two isolates in one case. The same organisms were not identified in cultures of the nasal and pharyngeal specimens from any patient, however, and none of these organisms was found in the domestic water supply of any of the patients.

The number of antibiotic courses prescribed (mean 2.75, range $0-6 /$ year) and hospital admissions with respiratory tract infections (mean $1 \cdot 25$, range $0-5 /$ year) after

Table 1 Sample collection and microbiological processing

\begin{tabular}{|c|c|c|}
\hline Sample/site & Mode of collection & Laboratory methods and culture media \\
\hline $\begin{array}{l}\text { Air flow from humidifier outflow port with } \\
\text { oxygen flow set at } 21 / \mathrm{min}\end{array}$ & $\begin{array}{l}90 \mathrm{~mm} \text { agar Petri dish held } 10 \mathrm{~cm} \\
\text { from port for } 1 \text { minute }\end{array}$ & Blood and Legionella $\mathrm{B}^{\star}$ agar plates \\
\hline $\begin{array}{l}\text { Water from humidifier } \\
\text { Water from tap used to fill humidifier chambs }\end{array}$ & Entire contents collected & Quantitative culture by surface plating of $0.5 \mathrm{ml}$ of watert \\
\hline $\begin{array}{l}\text { Water from tap used to fill humidifier chamber } \\
\text { Tip of inlet tube normally submerged in }\end{array}$ & Sampled after running for 30 seconds & on blood, MacConkie, and Legionella $M$ and $B$ agars \\
\hline $\begin{array}{l}\text { 1 ip of inlet tube normally submerged in } \\
\text { humidifier water }\end{array}$ & $\begin{array}{l}\text { One third of the surface area of agar } \\
\text { plate directly inoculated with tip }\end{array}$ & $\begin{array}{l}\text { Inoculum plated out over remainder of blood, MacConkie, and } \\
\text { Legionella } \mathrm{M} \text { and } \mathrm{B} \text { agars }\end{array}$ \\
\hline $\begin{array}{l}\text { Patient's nose } \\
\text { Patient's throat }\end{array}$ & $\begin{array}{l}\text { Moistened cotton tipped swab } \\
\text { Cotton tipped swab }\end{array}$ & Plated out on blood, MacConkie, and \\
\hline & $\begin{array}{l}\text { Swabs placed in Amies transport } \\
\text { medium after collection }\end{array}$ & \\
\hline
\end{tabular}

^BCYE Legionella agar with either a BMPA or a MWY (M) selective supplement was used. †Any semiquantitative water culture yielding too many colonies for accurate counting was repeated after it had been kept at $4^{\circ} \mathrm{C}$ overnight and three
serial 10 fold dilutions had been made. 
Table 2 Bacteria isolated from humidifier attachment water (colony forming units/ml)

\begin{tabular}{|c|c|c|c|c|c|}
\hline \multirow[b]{2}{*}{$\begin{array}{l}\text { Patient } \\
\text { No }\end{array}$} & \multirow[b]{2}{*}{$\begin{array}{l}\text { Humidifier } \\
\text { use }\end{array}$} & \multicolumn{4}{|c|}{ Bacteria isolated } \\
\hline & & $\begin{array}{l}\text { Klebsiella } \\
\text { aerogenes }\end{array}$ & $\begin{array}{l}\text { Pseudomonas } \\
\text { species }\end{array}$ & $\begin{array}{l}\text { Streptococcus } \\
\text { viridans }\end{array}$ & $\begin{array}{l}\text { Staphylococcus } \\
\text { epidermidis }\end{array}$ \\
\hline 1 & Continuous & $5.2 \times 10^{2}$ & - & - & - \\
\hline 2 & Continuous & - & $5.7 \times 10^{3}$ & - & - \\
\hline 3 & Continuous & - & $5.5 \times 10^{2}$ & $2.6 \times 10^{2}$ & - \\
\hline 4 & Continuous & - & $8.7 \times 10^{2}$ & - & - \\
\hline 5 & Continuous & - & - & - & $1.3 \times 10^{2}$ \\
\hline 6 & Continuous & - & - & $5.0 \times 10^{2}$ & - \\
\hline 7 & Continuous & - & $3.0 \times 10^{3}$ & - & - \\
\hline 8 & Intermittent & - & - & 一 & - \\
\hline
\end{tabular}

the patients acquired the humidifier attachment was much the same as before.

\section{Discussion}

This study found that water in the humidifier attachments on oxygen concentrators was usually contaminated with potentially pathogenic bacteria. Even though patients followed the manufacturer's instructions, the level of contamination and species of bacteria isolated are similar to those found in humidifiers attached to mechanical ventilators ${ }^{3}$ and in high humidity environments used with children. This finding is not surprising because any humidifying system attached to respiratory equipment is vulnerable to bacterial contamination. ${ }^{1}$ The only patient in this study found not to have an appreciably contaminated humidifier used the attachment intermittently.

Reassuringly, none of the patients had required more frequent courses of antibiotics or admissions to hospital with respiratory tract infection, suggesting that they had not had any increase in infection rate since starting to use the humidifier. The level of contamination in the humidifier may not have been sufficient to produce upper airways colonisation (as defined by culture of nasal and pharyngeal swabs), which epidemiological studies have shown to be a vital factor in the development of lower respiratory tract infec- tions. ${ }^{5}$ Furthermore, none of the patients in this study were suffering from serious intercurrent illness or receiving regular antimicrobial drugs, which reduce resistance to colonisation with potential pathogens. ${ }^{5-8}$ If such factors were present, conceivably organisms of low virulence typically growing in modest numbers in the humidifier water could cause a pulmonary infection. Such a possibility should be considered in a patient using an oxygen concentrator with a humidifier who presents with community acquired pneumonia.

1 Hovig B. Lower respiratory tract infections associated with respiratory therapy and anaesthesia. J Hosp Infect 1981;2:301-15.

2 Barnes KL, Clifford R, Holgate ST, et al. Bacterial colonisation of home nebulisers. BMJ 1987;295:812-3.

3 Phillips I, Spencer G. Pseudomonas aeruginosa cross-infection. Lancet 1965 ;ii:1325-7.

4 Hoffman MA, Finberg L. Pseudomonas infections in infants associated with high humidity environments. $J$ Pediatr 1955;46:626-30.

5 Johanson WG Jr, Pierce AK, Sanford JP, et al. Nosocomial respiratory infection with gram negative bacilli the significance of colonisation of the upper respiratory tract. Ann Intern Med 1972;77:701-6.

6 Pollack M, Charache P, Neiman RE, et al. Factors influencing colonisation and antibiotic-resistance patterns of Gram negative bacteria in hospital patients. Lancet 1972;ii:668-71.

7 Grabill JR, Marshall LW, Charache P, et al. Nosocomial pneumonia a continuing problem. Am Rev Respir Dis 1973;108:1130-40.

8 Philip JR, Spencer RC. Secondary respiratory tract infection in hospital patients: effect of antimicrobial agents and environment. BMJ 974; ;i:359-62. 